\title{
Red cell survival in biliary cirrhosis
}

\author{
R. HUME, J. M. WILliamsON, AND J. W. WHitelaW \\ From the Departments of Medicine and Haematology, Southern General Hospital, Glasgow
}

SYNOPSIS Studies were carried out on eight patients with primary biliary cirrhosis. Four patients were found to have a haemolytic anaemia; one had Coombs red cell antibodies. Two patients had evidence of splenic sequestration of red cells using the radio-chromium technique. There was a significant correlation between the red cell survival and the bromsulphthalein retention test and the red cell survival and the serum level of bilirubin. It was concluded that the anaemia of cirrhosis of the liver, including primary biliary cirrhosis, may be due to a number of mechanisms and a unifying hypothesis based on the degree of liver dysfunction is suggested.

A review of the literature (Subhiyah and AlHindawi, 1967) has shown that $54 \%$ of patients with cirrhosis of the liver have a shortened red cell survival, measured by the radiochromium technique. However, patients with primary biliary cirrhosis, as a group, have not been investigated from this point of view. The need for such a study was prompted by a patient who presented with a Coombs-positive autoimmune haemolytic anaemia and in whom investigations also revealed coincident biliary cirrhosis. As far as we are aware this combination of disease has not been previously reported.

\section{Material and Method}

Eight female patients with primary biliary cirrhosis were studied (Table I). The diagnostic criteria (Table II) were raised serum alkaline phosphatase and gamma globulin together with a positive immunofluorescent mitochondrial antibody test and a liver biopsy showing the histological features described by Goudie, MacSween, and Goldberg, (1966), and with or Received for publication 28 August 1969. without raised serum bilirubin and cholesterol levels. Bromsulphthalein retention studies were carried out on seven patients.

Red cell survival studies (Table III) were carried out in seven patients by the radioactive chromium technique (Mollison and Veall, 1955). (Red cell survival studies were not carried out in case 1 before therapy because of the acuteness of the haemolytic process.) This gave a measure of the red cell half life $\left(\mathrm{T}_{\ddagger}{ }^{51} \mathrm{Cr}\right)$ for each patient and thus of the degree of haemolysis. The mean $T_{1}{ }^{51} \mathrm{Cr}$ in six haematologically normal patients was $28 \pm 5(\mathrm{SD})$, range 22-35 days (Hume, Dagg, Fraser, and Goldberg, 1964). In order to determine whether or not the spleen was acting as an organ of erythrocyte sequestration, radioactivity was also measured by surface counting over the heart, liver, and spleen as described by Jandl, Greenberg, Yonemoto, and Castle (1956). A spleen/liver ratio at $T_{1}$ of at least $2 \cdot 3$ to 1 was considered to be evidence of splenic sequestration of a degree sufficient to suggest that splenectomy would relieve a haemolytic anaemia (Goldberg, Hutchison, and MacDonald, 1966). None of the patients lost blood from the alimentary tract during the study as determined by tests for faecal occult blood. 


\begin{tabular}{llllllll}
\hline No. & Sex & $\begin{array}{l}\text { Age } \\
(y r)\end{array}$ & Jaundice & $\begin{array}{l}\text { Pigmenta- } \\
\text { tion }\end{array}$ & $\begin{array}{l}\text { Xantho- } \\
\text { mata }\end{array}$ & $\begin{array}{l}\text { Spleen } \\
\text { Size (in.) }\end{array}$ & $\begin{array}{l}\text { Liver Size } \\
\text { (in.) }\end{array}$ \\
\hline 1 & F & 50 & + & + & - & 0 & 0.5 \\
2 & F & 53 & + & - & - & 2 & 1.5 \\
3 & F & 59 & - & - & - & 0 & 0.5 \\
4 & F & 54 & + & - & - & $(-)$ & 2 \\
5 & F & 67 & + & + & + & 0.5 & $2 \frac{1}{2}$ \\
6 & F & 61 & + & - & - & 2.5 & 2.5 \\
7 & F & 53 & - & + & - & 0.5 & 1.5 \\
8 & F & 54 & + & + & - & 0 & 1.0 \\
\hline
\end{tabular}

Table I Clinical features

\begin{tabular}{|c|c|c|c|c|c|c|c|}
\hline No. & $\begin{array}{l}\text { Serum } \\
\text { Bilirubin } \\
(m \mathrm{~g} \%)\end{array}$ & $\begin{array}{l}\text { Serum } \\
\text { Cholesterol } \\
(m g \%)\end{array}$ & $\begin{array}{l}\text { Serum } \\
\text { l Alkaline } \\
\text { Phospha- } \\
\text { tase } \\
\text { (K.A. units) }\end{array}$ & $\begin{array}{l}\text { Gamma } \\
\text { Globulin } \\
(\mathrm{g} \%)\end{array}$ & $\begin{array}{l}\text { Mito- } \\
\text { chondrial } \\
\text { Antibody } \\
\text { Titre }\end{array}$ & $\begin{array}{l}\text { Liver } \\
\text { Biopsy } \\
\text { Histology }\end{array}$ & $\begin{array}{l}\text { Percentage } \\
\text { BSP } \\
\text { Retention } \\
\text { at } 45 \text { min }\end{array}$ \\
\hline $\begin{array}{l}1 \\
2 \\
3 \\
4 \\
5 \\
6 \\
7 \\
7\end{array}$ & $\begin{array}{l}6.0 \\
2 \cdot 2 \\
0.5 \\
2.2 \\
1.9 \\
4.3 \\
0.3 \\
4.1\end{array}$ & $\begin{array}{l}600 \\
392 \\
312 \\
276 \\
460 \\
312 \\
247 \\
276\end{array}$ & $\begin{array}{l}30 \\
70 \cdot 8 \\
49 \cdot 5 \\
27 \cdot 6 \\
36 \cdot 0 \\
44 \cdot 9 \\
19 \cdot 8 \\
31 \cdot 6\end{array}$ & $\begin{array}{l}3.2 \\
3.8 \\
3.6 \\
3.7 \\
3.9 \\
3.7 \\
3.9 \\
4.6\end{array}$ & $\begin{array}{l}1 / 512 \\
1 / 2000 \\
1 / 2048 \\
1 / 128 \\
1 / 128 \\
1 / 512 \\
1 / 1024 \\
1 / 512\end{array}$ & $\begin{array}{l}+ \\
+ \\
+ \\
+ \\
+ \\
+ \\
+ \\
+\end{array}$ & $\begin{array}{r}38 \\
33 \\
11 \\
- \\
6 \\
25 \\
4 \\
26\end{array}$ \\
\hline
\end{tabular}

Table II Diagnostic features

\begin{tabular}{lllrllll}
\hline No. & $\begin{array}{l}\mathrm{Hb} \\
(\mathrm{g} \%)\end{array}$ & $\begin{array}{l}\text { Reticulo- } \\
\text { cytes }(\%)\end{array}$ & $\begin{array}{l}\text { WBC } \\
(\text { per cmm })\end{array}$ & $\begin{array}{l}\text { Platelets } \\
(\text { per cmm })\end{array}$ & $\begin{array}{l}T_{\frac{1}{2}}{ }^{51} \text { Cr } \\
(\text { days })\end{array}$ & $\begin{array}{l}\text { Spleen) } \\
\text { Liver } \\
\text { Ratio }\end{array}$ & $\begin{array}{l}\text { Coombs } \\
\text { Test }\end{array}$ \\
\hline 1 & $6 \cdot 8$ & 34 & 29,000 & 140,000 & & & + \\
2 & 140 & $<2$ & 7,500 & 178,000 & 18 & $1 \cdot 1: 1$ & - \\
3 & $12 \cdot 5$ & $<2$ & 4,800 & 245,000 & 23 & $1 \cdot 1: 1$ & - \\
4 & $12 \cdot 7$ & $<2$ & 11,300 & 164,000 & 22 & $(-)$ & - \\
5 & $12 \cdot 3$ & $<2$ & 8,700 & 224,000 & 24 & $3: 1$ & - \\
6 & $7 \cdot 7$ & $<2$ & 2,800 & 39,000 & 18 & $2 \cdot 5: 1$ & - \\
7 & $12 \cdot 5$ & $<2$ & 6,800 & 233,000 & 29 & $1 \cdot 1: 1$ & - \\
8 & $11 \cdot 7$ & $<2$ & 10,100 & 121,000 & 17 & $2 \cdot 1: 1$ & - \\
\hline
\end{tabular}

Table III Haematological data

An immunofluorescent antibody test was performed by the method of Goudie et al (1966).

Routine haematological measurements were carried out by the method of Dacie and Lewis (1963).

\section{Resuits}

The results of the red cell survival studies (Table III) showed that three patients (cases 2,6 , and 8 ) had a haemolytic anaemia, the red cell survival being 18 days, 18 days, and 17 days respectively, as compared with the normal red cell survival (22-35 days). Four patients had a red cell survival time within the normal range. One patient (case 1) had an acute haemolytic anaemia (Coombs positive). The gammaglobulin neutralization test showed a warm

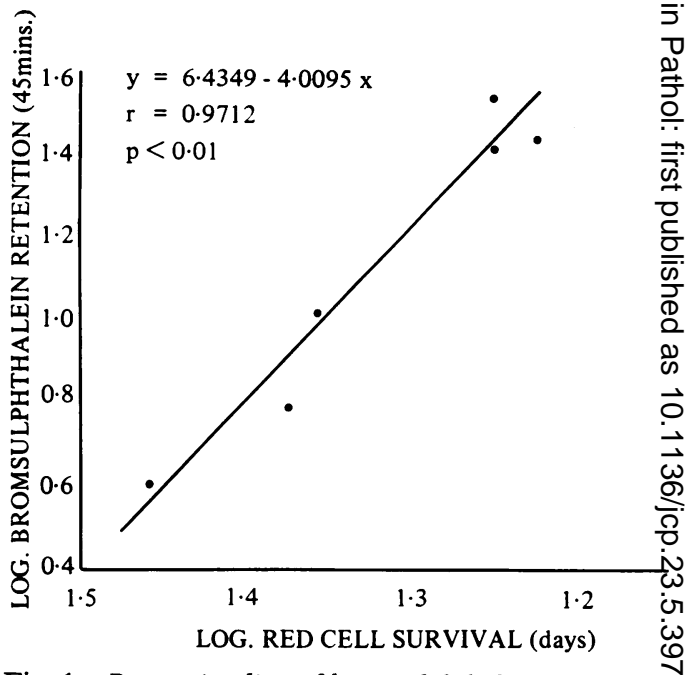

Fig. 1 Regression line of bromsulphthalein retention 0 on red cell survival expressed as a log-log line.

(IgG type) antibody which was found to have specificity of anti-Dc. Two patients (cases 5 and 6$)$ had evidence of splenic sequestration of red cells from surface counting, the spleen: liver ratio being $3: 1$ and $2 \cdot 5: 1$ respectively, and one patien (case 6) also had an associated leucopenia and thrombocytopenia with generalized hyperplasia of the bone marrow. There were no correlations found between the red cell survival and the size of the liver or spleen, and no correlation between the red cell survival and serum choles $\frac{0}{3}$ terol, serum alkaline phosphatase, serum gamma globulin level, and immunofluorescent mitochondrial antibody titre. However, in the six patients (cases 2, 3, 5, 6, 7, and 8) in whom red cell survival (RCS) could be related to the bromsulphthalein retention (BSP) a significane. relationship was found between these twos measurements (Fig. 1).

The regression of $\log y$ (BSP) on $\log x$ (RCS) is given by the equation $y=6.4349-4.0095 x^{\omega}$ giving the correlation coefficient $(r)$ of 0.9712 $(\mathrm{P}<0.01)$; the reduction in the red cell survivat is related to the degree of liver dysfunction when expressed as a log-log line.

In the seven patients (cases $2,3,4,5,6,7, \frac{0}{7}$ and 8) in whom red cell survival could be relatect to the serum bilirubin level (SB) a significan relationship was found between these two measurements (Fig. 2).

The regression of $y$ (SB) on $\log x$ (RCS) iso given by the equation: $y=23 \cdot 1631-15.789 x$ 을 giving a correlation coefficient (r) of 0.8496 . $(\mathrm{P}<0.05)$; the reduction in the red cell surviva is related to the increased level of serum bilirubin when expressed as a log-linear relationship. 


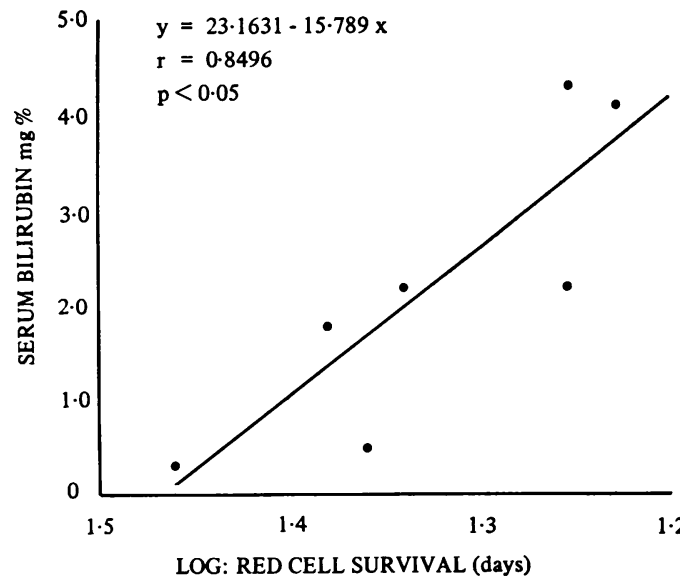

Fig. 2 Regression line of serum bilirubin in red cell survival expressed as a log-linear relationship.

\section{Discussion}

Reduced red cell survival measured by the radioactive chromium technique has been reported in approximately $54 \%$ of patients with liver cirrhosis (Subhiyah and Al-Hindawi, 1967) although the mechanism of this haemolytic anaemia remains in doubt. Subhiyah and AlHindawi (1967) assert from their own studies that 'splenic destruction of red cells is an important, if not the main, factor in the haemolytic process'. However, the application of statistical methods to their results shows that there is no significant correlation between radioactive excess spleen counts expressed as a percentage and the red cell survival measured at the half-time disappearance of radiochromium $\left(T{ }^{{ }^{51}} \mathrm{Cr}\right)$ in their 22 patients $(r=0.2904, P>0.05)$. Furthermore, although they found, by surface counting, an increased splenic accumulation of radioactivity in four of seven patients with cirrhosis whose $\mathrm{T}_{\frac{1}{2}}{ }^{51} \mathrm{Cr}$ was under 20 days, and an increased splenic uptake in only one of seven patients with cirrhosis whose $\mathrm{T}{ }^{{ }^{51} \mathrm{Cr}}$ was normal, this difference is not significant using the chi square test $\left(\chi^{2}=2.8 ; \mathrm{P}>0.05\right)$. However, when Student's $t$ test was applied to the mean spleen counts of these two groups a significant relationship was found $(t=1.8666$; $P<$ 0.05 ). It can be seen, therefore, that while there is a relationship between red cell survival and the splenic accumulation of radioactive chromium, this is not close. Most observers are convinced that the spleen plays the main part in the haemolytic process of at least some cases of cirrhosis of the liver (Jandl, 1955; Jones, Weinstein, Effinger, and Capps, 1955; Holzbach, Shipley, Clark, and Chudzik, 1964; Silva, Abu Jamra, Maspes, Pontes, Pieroni, and Cintra,
1965; Kimber, Deller, Ibbotson, and Lander 1965), but the evidence that this is the principal cause in general is lacking. Kimbero et al (1965) found an abnormal uptake of redf cells by the spleen in only three of 18 patientso with cirrhosis who had reduced red cell survival Discrepancies have also been described following? splenectomy in such patients. Hyman ande Southworth (1951) found splenectomy to be unsuccessful in six patients with cirrhosis with? a haemolytic anaemia, while Silva et $a \mathbb{R}$ (1963) found this operation to be successful in three of four patients, although portacaval anastomosis preceded the splenectomy. Chaplin and Mollison (1953) have reported reducect red cell survival in a patient with cirrhosis? who had had a splenectomy. It may be relevan to note that splenectomy is successful in onlyin $50 \%$ of unselected cases of acquired haemolyticer anaemia (Welch and Damashek, 1950).

$\omega$

Apart from the role of the spleen other mechanisms have also been implicated in the haemolytic process of cirrhosis of the liver:The Coombs antiglobulin test has revealed the presence of red cell antibodies on occasion (Hyman and Southworth, 1951; Jones et al, 1955) although such a finding seems not to be veryo frequent. Other studies have suggested that in some cases, at least, there is probably both an intracorpuscular and an extracorpuscular factop involved in the anaemia (Fauvert, Loverdog Nicollo, and Boivin, 1958; Hall, 1960; Combris $-\bar{D}$ son, 1960; Pitcher and Williams, 1963; Katz Velasio, Guzman, and Alessandri, 1964; Smith을 Lonergan, and Sterling, 1964).

The present series illustrates many of the factors so far described. Of the eight patients with biliary cirrhosis studied, four (cases 1, 2\% $6,8)$, ie, $50 \%$, had a shortened red cell survivab which is similar to that in patients with cirrhosis. in general. One patient (case 1) had an acute Coombs-positive autoimmune haemolytic anaemia. The significance of the red cell anti옥 bodies in the production of the anaemia is sug $\rightarrow$ gested by the remission in the anaemia when steroid therapy was introduced. The haemo+v globin rose from $6.8 \mathrm{~g}$ to $12.5 \mathrm{~g} \%$ and the PCV rose from $20 \%$ to $36 \%$, and the Coombs test became negative. Red cell survival is notw usually affected by steroid therapy in cirrhosis (Williams and Billing, 1961; Katz et al, 1964)을 Two patients (cases 5 and 6) had evidence from surface counting, of splenic sequestration of red cells of a degree which suggested that splen-군 ectomy would influence the haemolytic process $\frac{\text { Oे }}{0}$ Case 6 also had leucopenia and thrombocyto? penia with generalized hyperplasia of the bon marrow which was in keeping with the diagnosis of hypersplenism. Radiation to the spleen of this patient caused a reduction in splenic sizes from 3 in. to $1 \frac{1}{4}$ in. below the costal margin. and a remission in the anaemia. The haemo globin rose from $7.7 \mathrm{~g}$ to $12.7 \mathrm{~g} \%$ and the $\mathrm{PCV}$ 


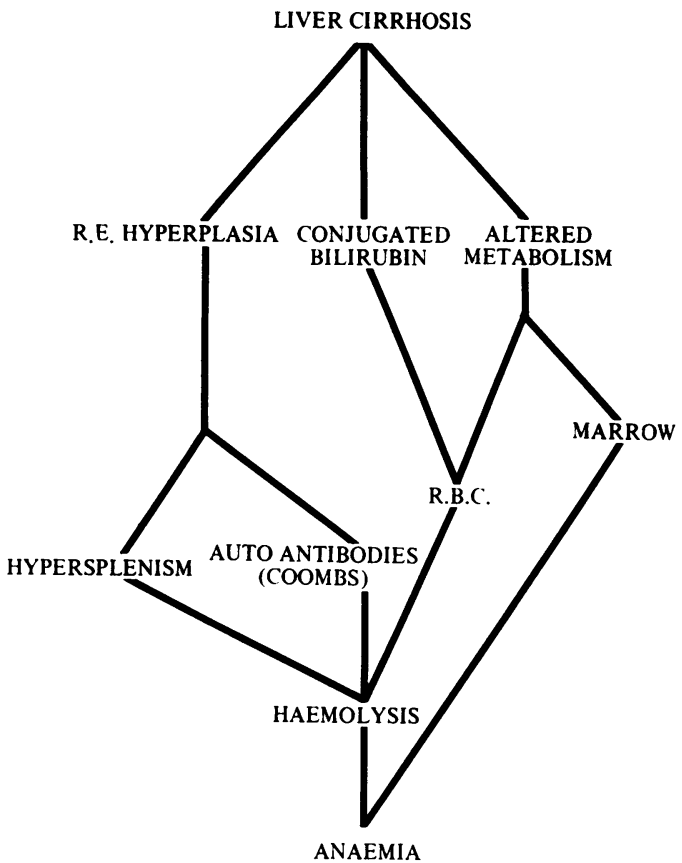

Fig. 3 Hypothetical relationship between cirrhosis of the liver and anaemia.

from $28 \%$ to $36 \%$. There was a moderate rise in the white cell count from approximately $2,500 / \mathrm{cmm}$ to $3,600 / \mathrm{cmm}$. There was no obvious change in the platelet count which continued around $40,000 / \mathrm{cmm}$. The remaining two patients (cases 2 and 8 ) had reduced red cell survival times which did not appear to relate to any of the factors so far discussed. Further analysis of the group as a whole failed to show any relationship between the red cell survival and the size of the liver or spleen or between the red cell survival and the serum cholesterol, alkaline phosphatase, serum gamma globulin, or the immunofluorescent mitochondrial antibody titre. However, there was a significant correlation between the serum bilirubin level and the red cell survival $(P<0.05)$. This unexpected finding may have relevance to the production of the haemolytic process when considered in the light of the experimental findings of Powell, Dunnicliff, and Billing (1968). These workers, following experiments in rats whose bile ducts had been ligated, suggested that 'the haemolytic process accompanying cholestatic jaundice may be related to the increased levels of conjugated bilirubin in the plasma, but not to the accumulation of conjugated bile acids, phospholipids, and cholesterol'. In the present series, it was not determined what percentage of the total serum bilirubin was made up of conjugated bilirubin, but it is tempting to suggest that conjugated bilirubin is the extracorpuscular factor in the haemolytic anaemia of biliary cirrhosis. Furthermore, in the six patients in $\cong$ whom there was both a red cell survival and $a$ BSP retention test available for analysis, $a \stackrel{\sim}{=}$ significant relationship was found between these $\underline{\underline{O}}$ two measurements $(\mathrm{P}<0.01)$. This is in keeping with the observations of Kimber et al (1965) made on a group of 24 patients with chronic 0 liver disease resulting from alcoholism, post-흠 necrotic scarring, or haemochromatosis. Stat- $\frac{\bar{\rho}}{\bar{Q}}$ istical analysis applied to their results shows $a \stackrel{\mathbb{Q}}{\Omega}$ significant correlation between red cell survival and the BSP test $(r=0.422 ; \mathrm{P}<0.05)$. It can ${ }^{\mathrm{C}}$ be concluded from this that the degree of liver? dysfunction is also an important factor in the $\overrightarrow{\vec{\omega}}$ production of the haemolytic anaemia and the $\sigma$ one which initiates all the other mechanisms.

From the available evidence, therefore, it i would appear, after excluding obvious causes ${ }_{i}^{\omega}$ such as iron deficiency due to haemorrage, $\omega$ vitamin $B_{12}$ and folic acid deficiency, which $\vartheta$ are probably of dietary origin, and relative 을 anaemia due to increased plasma volume, that the anaemia of cirrhosis of the liver, including $\subseteq$ primary biliary cirrhosis, results from an inter-action of different mechanism. We would suggest $\vec{\varphi}$ the following unifying hypothesis for the mech- $\triangle$ anisms (Fig. 3): cirrhosis of the liver, however produced, is associated with reticuloendothelialo hyperplasia and increased production of gamma globulin (Glynn and Holborow, 1965). This increase in the reticuloendothelial cell system $\frac{}{\varnothing}$

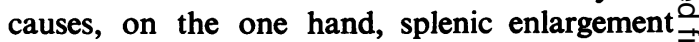
with, on occasion, 'hypersplenism' and on the other hand, on occasion, Coombs red cell antibodies with resulting haemolytic anaemia. The damaged liver also produces a 'metabolic' disturbance, including a raised serum conjugated bilirubin level which affects the red cells eithero intracellularly or extracellularly or both, render ing the cells more susceptible to destruction by the reticuloendothelial system generally, resulting in shortened red cell survival times. Finally, 을 for some reason unexplained, although probably $>$ also related to the 'metabolic' changes produced으․ by the diseased liver, the bone marrow fails to utilize iron for haem synthesis (Kimber et al, 1965) resulting in an inadequate marrow re- $N$ sponse to the haemolytic process. This model $\mathbb{E}^{N}$ may provide a useful guide to further researcho into this very complex subject.

We are grateful to Dr A. Dick for the liver histology reports, to $\mathrm{Dr} W$. S. Thomson for the $\mathrm{BSP}^{-}$ results, and to Dr R. B. Goudie for the mitochon- $\vec{D}$ drial antibody titres.

\section{Keferences}

Chaplin, H., Jr., and Mollison, P. L. (1953). Red cell life-spand in nephritis and hepatic cirrhosis. Clin. Sci., 12, 351-360. Combrisson, A. (1960). L'equilibre erythrocyaire des cirrhose $s \frac{0}{\text { du foie. Sang, 31, 885-904. }}$
.

Dacie, J. V., and Lewis, S. M. (1963). Practical Haematology. 3rd ed. Churchill, London. 
da Silva, L. C., Jamra, M. A., Maspes, V., Pontes, J. F., Pieroni, R. R., and Cintra, A. B. DeU. (1963). Pathogenesis of indirect reacting hyperbilirubinemia after portacaval anastomosis. Gastroenterology, 44, 117-124.

Fauvert, R., Loverdo, A., Nicollo, S., and Boivin, P. (1958). L'hemolyse dans les cirrhoses. Etude de 40 cas par la methode des hematies marquées du chrome 51. Sem. Hôp. Paris, 34, 1801.

Glynn, L. E., and Holborow, E. J. (1965). Autoimmunity and Disease. Blackwell, Oxford.

Goldberg, A., Hutchison, H. E., and MacDonald, E. (1966). Radiochromium in the selection of patients with haemolytic anaemia for splenectomy. Lancet, 1, 109-114.

Goudie, R. B., MacSween, R. N. M., and Goldberg, D. M. (1966). Serological and histological diagnosis of primary biliary cirrhosis. J. clin. Path., 19, 527-538.

Hall, C. A. (1960). Erythrocyte dynamics in liver disease. Amer. J. Med., 28, 541-549.

Haozbach, R. T., Shipley, R. A., Clark, R. E., and Chudzik, E. B. (1964). Influence of the spleen size and portal pressure on erythrocyte sequestration. J. clin. Invest., 43, 1125-1135.

Hume, R., Dagg, J. H., Fraser, T. N., and Goldberg, A. (1964). Anaemia of Felty's syndrome. Ann. rheum. Dis., 23, 267-271.

Hyman, G. A., and Southworth, H. (1951). Hemolytic anaemia associated with liver disease. Amer. J. med. Sci., 221, 448-456.

Jandl, J. H. (1955). The anemia of liver disease: observations on its mechanism. J. clin. Invest., 34, 390-404.
Jandl, J. H., Greenberg, M. S., Yonemoto, R. H., and Castle, W. B. (1956). Clinical determination of the sites of red cell sequestration in hemolytic anemias. J. clin. Invest $\overline{\overline{7}}$ 35, 842-867.

Jones, P. N., Weinstein, I. M., Ettinger, R. H., and Capps, R. Bu (1955). Decreased red cell survival associated with liver disease. Arch. intern. Med., 95, 93-102.

Katz, R., Velasco, M., Guzman, C., and Alessandri, H. (1964). Red cell survival estimated by radioactive chromiuri in hepatobiliary disease. Gustroenterology, 46, 399-404.

Kimber, C., Deller, D. J., Ibbotson, R. N., and Lander, Fo (1965). The mechanism of anaemia in chronic liver disease. Ouart. J. Med., 34, 33-64.

Mollison, P. L., and Veall, H. (1955). Use of the isotope "C. as label for red cells. Brit. J. Haemat., 1, 62-74.

Pitcher, C. S., and Williams, R. (1963). Reduced red cell survival i jaundice and its relation to abnormal glutathione metabop ism. Clin. Sci., 24, 239-252.

Powell, L. W., Dunnicliff, M. A., and Billing, B. H. (19685 Red cell survival in experimental cholestatic jaundice. Brit. J. Haemat., 15, 429-435.

Smith, J. A., Lonergan, E. T., and Sterling, K. (1964). Spur-ceff anemia. Hemolytic anemia with red cells resemblin acanthocytes in alcoholic cirrhosis. New Engl. J. Med 271, 396-398.

Subhiyah, B. W., and Al-Hindawi, A. Y. (1967). Red cell survivit and splenic accumulation of radiochromium in livis cirrhosis with splenomegaly. Brit. J. Haemat., 13, 773-778,

Welch, C. S., and Dameshek, W. (1950). Splenectomy in blook dyscrasias. New Engl.J. Med., 242, 601-606.

Williams, R., and Billing, B. H. (1961). Action of steroid theraps in jaundice. Lancet, 2, 392-396. 